\title{
On the current status of Indian Peafowl Pavo cristatus (Aves: Galliformes: Phasianidae): keeping the common species common
}

\author{
K. Ramesh ${ }^{1,2}$ \& Philip McGowan ${ }^{2}$ \\ ${ }^{1}$ Wildlife Institute of India, Post Box 18, Chandrabani, Dehradun, Uttarakhand 248001, India \\ ${ }^{2}$ World Pheasant Association, 7/9 Shaftesbury Street, Fordingbridge, SP6 1JF, United Kingdom \\ E-mail: ${ }^{1}$ ramesh @ wii.gov.in
}

Date of online publication 26 February 2009 ISSN 0974-7907 (online) | 0974-7893 (print)

Editor: Sanjay Molur

\section{Manuscript details:}

Ms \# 01845

Received 28 August 2007

Final revised received 26 December 2007

Finally accepted 16 January 2008

Citation: Ramesh, K. \& P. Mcgowan (2009). On the current status of Indian Peafowl Pavo cristatus (Aves: Galliformes: Phasianidae): keeping the common species common. Journal of Threatened Taxa 1(2): 106-108.

Author Details: Dr. K. RAMESH is a faculty member with Wildlife Institute of India and is involved in the landscape analysis of Galliformes distribution in northwestern India. His doctoral thesis was on the ecology of three sympatric pheasant species in the Great Himalayan National Park, Himachal Pradesh. Dr. PHILIP McGowan researched on the Malaysian Peacock Pheasant for his Ph.D. and is currently the Director of World Pheasant Association, U.K., an organization devoted to the conservation of the world's Galliformes species.

Author contributions: The first author conceived the idea and prepared the manuscript, while the second author provided necessary conceptual and technical inputs.

Copyright: ( ) K. Ramesh \& P. McGowan 2009. Creative Commons Attribution 3.0 Unported License. JoTT allows unrestricted use of this article in any medium for non-profit purposes, reproduction and distribution by providing adequate credit to the authors and the source of publication.

Acknowledgements: The authors are thankful to the Director, Wildlife Institute of India and the two reviewers for their useful inputs. Wildlife Institute of India

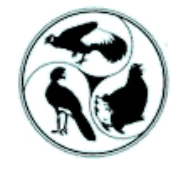

OPEN ACCESS | FREE DOWNLOAD
Abstract: It is ironic that while all efforts to save the Tiger (Panthera tigris) are underway, another species of national importance, the Indian Peafowl, (Pavo cristatus) is still to receive adequate attention. Illegal trade for train-feathers and mass mortality due to indiscriminate application of pesticides and herbicides in crop-fields are major causes of the recent decline in peafowl numbers. Though there has been increasing concern over the declining peafowl population, it is difficult to arrive at a realistic plan unless the current population size, the rate of decline and the causes of decline are scientifically quantified. Considering the need for conservation initiatives for peafowl, one must look beyond the 'fire-fighting approach' towards 'keeping the common species common' in order to be efficient with conservation investments and instill greater public participation.

Keywords: Conservation, distribution, peafowl, pheasant, population estimation

\section{INTRODUCTION}

The Indian Peafowl (Pavo cristatus), also called Blue or Common Peafowl, is the largest of the pheasants. It was justifiably declared as the National Bird of India in 1963 due to its 'flagship' value founded on its glorious position in mythology and its widespread distribution and grandeur. The peacock's large body size, brilliantly ornamented plumage and long train-feathers are surely attractive to predators, and it remains a puzzle why such an extravagant trait has developed despite being a handicap to escape predation pressure, among other things. One explanation is that of Zahavi's (1975) 'handicap hypothesis' which suggests that a peacock's long train-feathers are an honest signal of fitness as the individual has demonstrated its survival ability even with the disadvantage of having to carry around such a heavy and conspicuous burden. Consequently, females would consciously choose the male to mate with precisely because of its 'handicap', rather than in spite of it (Gadagkar 2003) and thus pass on the genes to the next generation. Though the peafowl's physical appearance and behaviour have always interested and intrigued naturalists, there are very few studies of its ecology, population status and conservation threats. The aim of this note is to highlight this huge gap in our understanding of this species and to suggest some action plans.

\section{Distribution}

The natural range of Indian Peafowl is essentially the Indian subcontinent, with India covering a vast majority of its range from the outer Himalaya (up to 2000m) through much of the country including the peninsula. Other countries where the species still survives in good numbers are Nepal and Sri Lanka; while there are only two populations in Pakistan, it is rare in Bhutan and possibly extinct in Bangladesh. It has been introduced in Andaman Islands (Ali \& Ripley 1980). Peafowls have been maintained in captivity for centuries across the world and there are introduced populations in USA, Europe, Hawaii Islands, West Indies, South Africa, New Zealand, Australia etc. (Madge \& McGowan 2002).

\section{Habitat ANd behaviour}

It is a bird of scrub-jungles and forest edges, showing affinity to moist and dry deciduous and semiarid biomes. It is also found in agriculture fields, along streams with good vegetation and close to human habitations in a semi-feral condition (Johnsgard 1986). It roosts on trees and also uses tall buildings where trees are scarce. It generally prefers a habitat mosaic of scrub and open areas, with adequate sites for 'dust bathing' and 'lekking', a phenomenon where males are known to congregate in open areas for 
displaying to attract females (Yasmin \& Yahya 1996). Dust bathing is critical as this bird has to condition its feathers and remove feather-degrading bacteria and other external parasites. It is likely that the availability of such habitats partly explains the relatively high abundance of this species in semi arid and flood plains.

\section{Population status}

In the absence of reliable information and data, it is hard to place the current distribution status and population size of the species; although a conservative 'guesstimate' suggests that the population may exceed 100,000 (Madge \& McGowan 2002). While the species is becoming locally extinct from several parts of its former range due to habitat conversion and changes in the cropping pattern (Imam 2005), poaching, and pesticiderelated issues, there is no estimate of the size of surviving populations and the rate of loss from the entire country. Only recently the states of Himachal Pradesh, Uttarakhand and Gujarat have initiated statewide surveys for these birds, but the estimates are not yet available. These estimates would reflect only the minimum population size, requiring further investigation to fully understand the population status in these areas. Population estimates could also be derived from the recently-concluded tiger population estimation project, which gathered data on peafowl numbers as a part of prey estimation (Jhala et al. 2005). However, this was mostly carried out in the forested areas of tiger habitat and thus covered only a small portion of the actual peafowl habitat. The Wildlife Institute of India has conducted a questionnaire survey on population status of Indian peafowl (Choudhury \& Sathyakumar 2007), and this again would only be a pointer for further investigation unless the estimates are substantiated with empirical data. Other sources of information could be the dissertation studies carried out by some universities and projects on carnivores and their prey estimation, wherein peafowl abundance also figures in terms of available prey densities and biomass. However, such efforts are not many, and have also been carried out over varying time scales making it difficult to draw general conclusions. Though compiling this data would be useful to understand the population size in given localities, it is certainly insufficient to make any extrapolation to population estimates for large regions of the country as a whole.

In short, there is no reliable estimate of the current population status of Indian Peafowl for the country, and it is important to carry out intensive field sampling if one is to arrive at a reliable estimate of the population.

\section{Conservation status}

The Indian Peafowl is listed as Least Concern species in the Red List of International Union for Conservation of Nature (BirdLife International 2008), probably owing to its widespread distribution, occurrence of locally abundant semiferal populations, and protection from people on religious grounds. In India, it is given the utmost protection by inclusion in the Schedule I of Indian Wildlife Act, 1972. Although the train feathers of the Indian Peafowl are traded for various reasons, it is not included on any Appendix of the Convention on International Trade of Endangered Species perhaps on the claim that these feathers are naturally fallen ones during annual molt of the species, and also that the scale of trade across international border is still to be understood.

\section{Threats}

The Indian Peafowl is under threat from various quarters that include the demand for feathers and wild meat, conflict with farmers during cropping season, increased use of chemical fertilizers and pesticides, and habitat degradation. An adult peacock has about 200 tail feathers, which it sheds from August onwards; fully-developed new feathers appear in February (Sharma 1974; Ali \& Ripley 1980). The fallen feathers are collected and sold in local markets and the birds are also reportedly killed to increase revenue return. Other threats include habitat degradation and loss - more significantly from conversion of their habitat to agriculture, habitation and industrial growth, poisoning to counter crop damage, consumption of eggs and fat extracts for alleged medicinal values, and killing for wild meat (del Hoyo et al. 1994; Chakkaravarthy 2002). Although these threats are believed to be causing an alarming decline in populations, the magnitude and pattern of the effects in different parts of the country are yet to be quantified.

\section{What has to be done?}

It is critical that urgent efforts are made to understand the habitat and population status of the species through field based research and in situ conservation projects. A meeting of the Indian Board for Wild Life (held on 19 June 2006) underlined the need for such efforts. The actions required are: (1) mapping of habitat and distribution status of the species across the country, inside and outside protected areas; (2) time series analysis of habitat change to quantify the rate of change and identify high-risk areas and potential sites for further affirmative action; (3) estimation of population size by established count methods such as line transect, call counts and roost counts; (4) intensive ecological investigations in representative sites in major biogeographic zones with focus on the effects of threats in relation to breeding success and survival probability; (5) quantification of trade, with details on source and people involved; and (6) undertaking outreach activities to sensitize local communities, which may be carried out by a network of 'student clubs' (e.g. National Green Corps) throughout the country. These people could be trained to collect population data and undertake monitoring within their localities, and the reliability of the results could be ensured by adopting rigorous protocols. These ambitious initiatives should be executed through consultative processes involving various research and conservation agencies in the country.

The reason for the precarious status of many species including peafowl is the consistent bias towards endangered species and conservation interventions that are based on restrictive models (protected area-centric conservation). This approach overlooks common species when planning and implementing research and conservation schemes. Though this policy was essentially triggered by limited resources and a desire to safeguard a few charismatic species thought to be highly threatened, it has remained the major conservation policy even though our understanding of biodiversity conservation issues has increased substantially. In practice, this does not encourage imaginative thinking about alternative options and mobilising resources for a broader plan. This myopic approach 


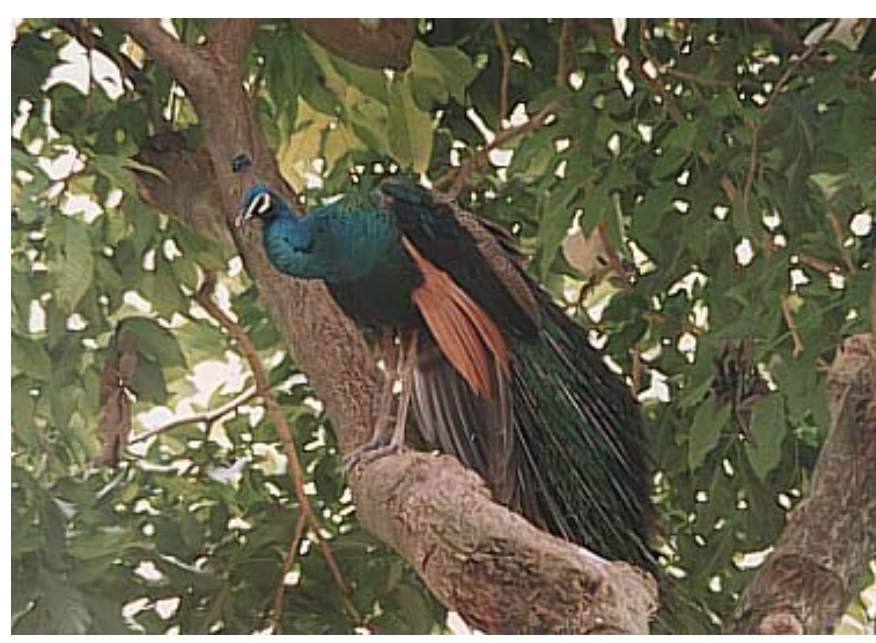

Images 1 \& 2. Peacock. By World Pheasant Association, U.K

often results in common species becoming threatened, and thus requiring greater human and fiscal resources than would have been the case if some thought had been given to broader conservation issues. Therefore, while concentrating on threatened species management, efforts should simultaneously be made to mobilize resources and develop strategies for 'keeping the common species common'. The Indian Peafowl the National Bird of India - is a clear case in this direction, and if full-fledged efforts are not taken up now it may soon follow the trail of the vanishing vultures of the subcontinent.

\section{References}

Ali, S. \& S.D. Ripley (1980). Handbook of The Birds of Indian and Pakistan, Volume 2: Magapodes to Crab Plover. Oxford University Press, New Delhi, 347pp.

BirdLife International (2008). Pavo cristatus. In: IUCN 2008. 2008 IUCN Red List of Threatened Species. <www.iucnredlist.org $>$. Downloaded on 03 February 2009.

Chakkaravarthy, Q.A. (2002). Call to save our national bird, Indian Peafowl (Pavo cristatus). Proceedings of the National Symposium on Galliformes, Division of Wildlife Biology, AVC College, Bharathidasan University, Tamil Nadu, 77-78.

Choudhury, B. \& S. Sathyakumar (2007). Current status of the Indian peafowl. Mor, Newsletter of World Pheasant Association-India $7 \mathrm{pp}$.

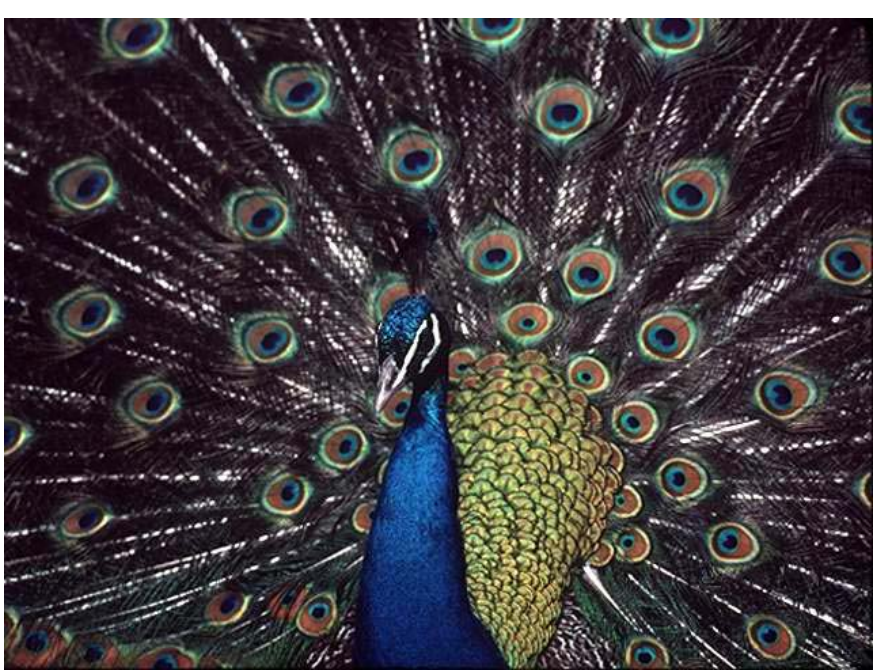

del Hoyo, J., A. Elliot \& J. Sargatal (1994). Handbook of The Birds of The World. New World Vultures to Guineafowl - Volume 2. Lynx Edicions, Barcelona, pp.434-552.

Gadagkar, R. (2003). Is the peacock merely beautiful or also honest? Current Science 85(7): 1012-1020.

Imam, E. (2005). Population status and conservation of Indian Peafowl Pavo cristatus in Aligarh, northern India, pp.191-193. In: Fuller, R.A. \& S.J. Browne (eds). Galliformes 2004. Proceedings of the 3rd International Galliformes Symposium. World Pheasant Association, Fordingbridge, United Kingdom.

Jhala, Y.V., Q. Qureshi \& R. Gopal (2005). Monitoring Tiger, Copredators, Prey and Their Habitat. Technical publication of Project Tiger Directorate, New Delhi and Wildlife Institute of India, Dehradun, $55 \mathrm{pp}$.

Johnsgard, P.A. (1986). The Pheasants of The World. Oxford University Press, New York, 295pp.

Madge, S. \& P. McGowan (2002). Pheasants, Partridges and Grouse, Including Buttonquails, Sandgrouse and Allies. Helm Identification Guides, Christopher Helm, London, 488pp.

Sharma, I.K. (1974). Ecological studies of the plumes of the peacock (Pavo cristatus). Condor 76(3): 344-346.

Yasmin, S. \& H.S.A. Yahya (1996). Correlates of mating success in Indian Peafowl. The Auk 113(2): 490-492.

Zahavi, A. (1975). Mate selection - a selection for a handicap. Journal of Theoretical Biology 53: 205-214. 